\title{
Upadek u szczytu kariery. Ostatnie lata Józefa Kazimierza Kossakowskiego (17921794)
}

\author{
The fall at the peak of the career. The last few years of Józef \\ Kazimierz Kossakowski (1792-1794)
}

\begin{abstract}
Streszczenie:
Okres od roku 1792 do śmierci (1794) był dynamicznym czasem w karierze Józefa Kazimierza Kossakowskiego. Odegrał on ważną rolę w organizacji konfederacji na Litwie. Razem z bratem Szymonem zaprowadził na Litwie rządy terroru, które przerodziły się w grabież majątku przeciwników. Kossakowscy przyczynili się do zatwierdzenia przez sejm III rozbioru Polski (1793). Nie mając odwrotu, Józef Kazimierz wiedział, że polegać może tylko na rosyjskich protektorach. Próbował więc zrobić wszystko, by spacyfikować Warszawę, gdzie dało się już odczuć przyspieszenie prac konspiracyjnych. Rady biskupa, by w razie problemów wystąpić zbrojnie przeciwko ludności stolicy, pogrążyły go. Wybuch powstania zastał Kossakowskiego w Warszawie. Po krótkim pobycie w więzieniu i pod wpływem warszawskich mieszczan został skazany na śmierć i powieszony - podobnie jak jego brat Szymon, stracony wcześniej w Wilnie. Tragiczny koniec nie może jednak przesłonić wielowymiarowości postaci Józefa Kazimierza Kossakowskiego, oświeconego sarmaty, którego karierę należy rozpatrywać w szerszym kontekście.
\end{abstract}

Słowa kluczowe: Kościół katolicki, Kossakowscy, insurekcja, sejm grodzieński, konfederacja targowicka

\section{Abstract:}

The period between 1792 and the hanging of Józef Kazimierz Kossakowski in 1794 was dynamic in his career. He played an important role in fast organisation of the 
Kamil Michaluk - Upadek u szczytu kariery...

confederation in Lithuania. Later, along with his brother Szymon, they established the rule of political terror which due to the emergency acts turned into looting of their enemies' properties. Kossakowski brothers became problematic to the point that a new Russian envoy Jakob Sievers decided to finish their ruling. It was a partial success though, because the brothers were needed to legitimize the partition of Poland on the Grodno Sejm. They had contributed to it a lot, evoking even more hatred towards them. Having no possibility to turn back, Józef Kazimierz knew that he could rely only on Russian protectors. He tried then to do everything to pacify Warsaw, where one could feel the acceleration of conspiratorial work. The advices given by the Bishop to, in case of problems, use armed forces against the citizens of the capital city, finally plunged him. The uprising's breakout found Kossakowski in Warsaw. After a short time in prison, under the pressure of citizens, he was sentenced to death and hanged, along with his brother, who had been killed in Wilno. However, this tragic ending cannot overshadow many dimensions of the character of Józef Kazimierz Kossakowski, an enlightened Sarmatian, whose career should be considered in a broader context.

Keywords: Catholic Church, Kossakowski, uprising, Grodno Sejm, Targowica Confederation

Biskup inflancki Józef Kazimierz Kossakowski (1738-1794) pozostawił interesujący dorobek literacki, ale i złą sławę zdrajcy¹. Jego życiorys obfitował w plany i dążenia, którym towarzyszyły zbyt małe możliwości finansowe ich realizacji. Logiczne było z jego perspektywy poszukiwanie możnego protektora. Znalazł go w osobie posła rosyjskiego Ottona von Stackelberga. W pierwszych miesiącach Sejmu Czteroletniego Kossakowski był uważany za jednego z „Moskali”. Klęska stronnictwa rosyjskiego $\mathrm{z}$ prymasem Michałem Poniatowskim sprawiła, że biskup znalazł się w fatalnej sytuacji. Nie uzyskał upragnionego bogatego biskupstwa, choć starał się o następstwo w Wilnie czy Krakowie. Pozostawał lojalny wobec Rosji i nie przestawał wie-

10 karierze biskupa Kossakowskiego pisali przede wszystkim: Zob. A. Zahorski, Józef Kazimierz Kossakowski, „Polski Słownik Biograficzny” (dalej: PSB), t. XIV, s. 268272; M. Rutkowska, Józef Korwin Kossakowski, [w:] T. Kostkiewiczowa (red.), Pisarze Polskiego Oświecenia, Warszawa 1994, s. 356-386; S. Kościałkowski, Antoni Tyzenhauz, Londyn 1970; W. Przyałgowski, Żywoty biskupów wileńskich, t. III, Petersburg 1860; J. Kurczewski, Biskupstwo wileńskie od jego założenia aż do dni obecnych, zawierające dzieje i prace biskupów i duchowieństwa (...), Wilno 1912. 
rzyć, że tylko tą drogą może zrealizować swoje ambicje. Zwlekał z podpisaniem aktu Konstytucji 3 maja, ale nie wystąpił jawnie przeciw niej; z końcem 1791 roku otrzymał koadiutorię wileńską². Następstwo po Ignacym Massalskim miało skłonić go do uległości wobec dzieła reform, ale tak się nie stało i w obliczu rosyjskiej agresji biskup inflancki opowiedział się po stronie agresora ${ }^{3}$.

Niestety, wśród kilku prac poświęconych karierze Józefa Kazimierza Kossakowskiego brakuje opracowań dotyczących roli, jaką odegrał w ostatnich latach istnienia I Rzeczpospolitej. Nawet wśród wiodących źródeł drukowanych dla tego okresu nie brakuje wzmianek o nikczemnej, ale ważnej działalności biskupa inflanckiego ${ }^{4}$. Co prawda literatura poświęcona wydarzeniom politycznym tych czasów często wspomina Kossakowskiego, jednak brakuje w niej klarownych

\footnotetext{
2 Więcej: R. Butterwick, Bishop Józef Kazimierz Kossakowski at the Four Years' Diet [w:] R. Šmigelskytè-Stukienė (red.), Lietuvos Didžiosios Kunigaikštystès istorijos kraštovaizdis. Moksliniu straipsniu rinkinys Skiriama profesorès Jūratès Kiaupienès 65mečiui, Vilnius 2012.

${ }^{3}$ Niejako automatycznie można więc nakreślić ramy chronologiczne artykułu. Wydarzeniem, które je rozpoczyna jest rosyjska interwencja w Rzeczpospolitej, która kazała Józefowi Kazimierzowi Kossakowskiemu jasno opowiedzieć się po stronie agresora i wziąć udział w od dawna przygotowywanych strukturach konfederacji. Drugą cezurą jest śmierć biskupa inflanckiego na insurekcyjnej szubienicy (9 maja 1794 r.).

${ }^{4}$ J. K. Kossakowski, Uwagi nad pismem pt. Uniwersał do narodu pod dniem 29 maja 1792, b. m., 1792; J. U. Niemcewicz, Fragment Biblie Targowickiej. Księgi Szczęsnowe, Frankfurt 1793; Targowica i sejm grodzieński 1793 w relacjach posła pruskiego Buchholtza, oprac. H. Kocój, Kraków 2004; J. J. Sievers, Jak doprowadziłem do drugiego rozbioru Polski, Warszawa 1992; A. Trębicki, Opisanie sejmu 1793 r. O rewolucji 1794 r., wyd. J. Kowecki, Warszawa 1962; M. K. Ogiński, Pamiętniki Michała Ogińskiego o Polsce i Polakach, t. 1, Poznań 1870; J. J. Patz, Z okien saskiej ambasady. Warszawa 1784 roku $w$ świetle relacji dyplomatycznych przedstawiciela Saksonii $w$ Polsce, wyd. Z. Libiszowska, H. Kocój, Warszawa 1969; J. Pistor, Pamiętniki o rewolucji polskiej roku 1794, oprac. B. Cholewiński, Warszawa 1906, s. 17- 19. Por. J. Kopeć, Dziennik (...) brygadiera wojsk polskich, Warszawa 1975; J. Kiliński, Pamiętniki, oprac. S. Herbst, Warszawa 1958; Akty Powstania Kościuszki, oprac. Sz. Askenazy, W. Dzwonkowski, t. I, Protokoły i dzienniki Rady Zastępczej Tymczasowej i Rady Najwyższej Narodowej, cz. I, Kraków 1918.
} 
Kamil Michaluk - Upadek u szczytu kariery...

ocen jego funkcji ${ }^{5}$, które mogłyby dać pewne podstawy do badań nad całościową biografią hierarchy.

Warto przyjrzeć się okolicznościom, w których biskup inflancki wystąpił otwarcie jako „moskiewska kreatura” na forum życia politycznego Rzeczpospolitej. Ostatnie lata jego życia odsłoniły też mechanizm funkcjonowania konfederacji targowickiej: tylko dzięki specjalnym prawom Kossakowscy mogli terrorem i konfiskatami zdobyć silną pozycję na Litwie. Działania te przyczyniły się do ich rodzinnego dramatu, gdy powieszeni zostali Józef Kazimierz i jego brat Szymon.

Szymon Kossakowski pierwszy przybył do Petersburga. W połowie marca dołączyli do niego pozostali „emigranci”, spotykając się z niechęcią wśród samych Rosjan ${ }^{6}$. Sz. Kossakowski w randze generałalejtnanta dowodził 8 tysiącami żołnierzy w okolicach Połocka. Była to pierwsza część korpusu gen. Michaiła Kreczetnikowa7. Lokalizacja nie była przypadkowa - Kossakowski operował już na tych terenach w czasach barskich ${ }^{8}$. Gra szła również o pozyskanie starego, ale majętnego kanclerza Aleksandra Sapiehy jako przywódcy konfederacji na Litwie 9 . Szymon stanął nad Dźwiną 30 kwietnia i posłał bratu pieniądze „na przekupienie wojska i obywateli”, prosząc o napisanie aktu konfederacji litewskiej10. Liczył na przeciągnięcie na rosyjską stronę hierarchów i wiernych Kościoła ${ }^{11}$. Nie doczekano się szlacheckich tłumów, które miały chętnie ciągnąć do Szczęsnego Potockiego, Seweryna Rzewuskiego czy właśnie Kossakowskich², których pragmatyzm anonimowy poeta zawarł w paszkwilu na Józefa Kazimierza: „Biskup

\footnotetext{
5 Wymienić trzeba zwłaszcza prace: A. Wolański, Wojna polsko-rosyjska $1792 r$. Kampania litewska, t. II, Poznań 1924; W. Smoleński, Konfederacja targowicka, Kraków 1903; D. Rolnik, O postawach szlachty litewskiej wobec konfederacji targowickiej w 1792 roku, „Wschodni Rocznik Humanistyczny” 2004, Nr 1.

6 P. Derdej, Zieleńce- Mir- Dubienka, Warszawa 2008, s. 32-33.

${ }^{7}$ A. Wolański, Wojna..., dz. cyt., s. 10.

8 Tamże, s. 13.

${ }^{9}$ Zob. Z. Zielińska, Aleksander Michał Sapieha [w] PSB, t. XXXV, s. 565-569.

10 W. Smoleński, Konfederacja..., dz. cyt., s. 97.

11 Tamże, s. 44.

12 D. Rolnik, Szlachta koronna wobec konfederacji targowickiej (maj 1792 - styczeń 1793), Katowice 2000, s. 65-67 i inne.
} 
przystojny, mówca zabawny/ Kursor wyborny, gracz w wista sławny/ Intrygant wieczny, podszyty cnotą/ Króla i naród odda za złoto"13.

Organizacja struktur konfederackich na Litwie stała się palącym problemem, a wyłonienie marszałków i konsyliarzy napotykało trudności ${ }^{14}$. Spośród 31 sejmików litewskich 27 zaprzysięgło, a 4 zaręczyły Konstytucję 3 maja ${ }^{15}$. Szlachta nie chciała poprzeć obcej interwencji16. Ciężary spadające na ludność ze strony wojsk rosyjskich i konfederatów wzmagały niezadowolenie. Wiele światła rzucają na sprawę słowa zawarte w artykule Dariusza Rolnika o postawach szlachty litewskiej wobec konfederacji targowickiej: „(...) inne były warunki rozwoju konfederacji targowickiej na Litwie i w Koronie. Różnice w tym względzie wynikały przede wszystkim ze zdecydowanie większej konsekwencji i determinacji Kossakowskich (...)"17. Formuła konfederacji i jej nadużywanie przez Kossakowskich dały podstawę dla terroru polityczno-ekonomicznego. Skutkowało to nie tyko emigracją szlachecką do Prus ${ }^{18}$, ale też faktem, że Szymon i Józef Kazimierz wraz z członkami rodu „trzęśli Litwą”, co zauważył Franciszek Karpiński19.

Zagarnięcie władzy umożliwiło Kossakowskim zaplecze polityczne, jakie zapewnili sobie w Moskwie ${ }^{20}$; posługiwali się oddziałami rosyjskimi, co dawało im przewagę. Przechwyciwszy władzę, utwierdzili ją przez licznych krewnych ${ }^{21}$ - w Generalności Litewskiej zasiadło ośmiu

\footnotetext{
13 J. Nowak, Satyra polityczna Sejmu Czteroletniego, Kraków 1933, s. 191.

14 W. Smoleński, Konfederacja..., dz. cyt., s. 99-100.

15 D. Rolnik, O postawach szlachty..., dz. cyt., s. 73. s. 22.

16 Poparły ją głównie „niespokojne żywioły”. Zob. A. Wolański, Wojna..., dz. cyt.,

17 D. Rolnik, O postawach szlachty litewskiej wobec konfederacji targowickiej w 1792 roku, „Wschodni Rocznik Humanistyczny” 2004, nr 1, s. 74.

18 Tamże.

19 Zob. F. Karpiński, Pamiętniki, Poznań 1884, s. 101-104, 105, 130.

20 W. Smoleński, Konfederacja..., dz. cyt., s. 114.

${ }^{21}$ Jak wspominał J. Kitowicz: „Kossakowski, nowy hetman litewski, podczas nabożeństwa siedział blisko ołtarza, na krześle ozdobionym kobiercami, a brat jego, biskup inflancki, koadiutor wileński, dogadzając pysze, nie miał wstydu incensować kadzidłem brata swego". J. Kitowicz, Pamiętniki, czyli Historia polska, oprac. P. Matuszewska, Warszawa 1971, s. 515.
} 
Kamil Michaluk - Upadek u szczytu kariery...

Kossakowskich ${ }^{22}$. Stosowali bezwzględną politykę względem opozycji politycznej, ale też tych, dzięki którym mogli się wzbogacić. Służyły temu tzw. „sancity” - dekrety konfederackie wydawane przeciwko politycznym wrogom, skutkujące spustoszeniem ich dóbr przy pomocy „egzekucji wojskowej”23. Kossakowscy powiększyli swój majątek o 2,5 mln złotych właśnie dzięki umiejętnemu posługiwaniu się możliwościami prawnymi, które dawała konfederacja ${ }^{24}$. Przykładem działania i wywierania presji poprzez „sancity” był kazus Michała Ogińskiego, który naraził się Sz. Kossakowskiemu ${ }^{25}$; podobnie było w przypadku Teodora Żaby ${ }^{26}$. Dobrze podsumował to D. Rolnik, twierdząc, że: „(...) Trudno się $w$ ich działaniach doszukiwać jakiejś idei państwowotwórczej, w środowisku tym dominowała głównie chęć bogacenia $\operatorname{się~}(\ldots)^{\prime 27}$.

Biskup Kossakowski przybył do Wilna z rodzinnego Janowa 16 maja 1792 r. $^{28}$. Towarzyszyło mu 200 kozaków, a wjazd odbył się na „zaproszenie" mieszczan sterroryzowanych przez Szymona Kossakowskiego ${ }^{29}$. Zajęciu miasta towarzyszyły uroczystości religijne z nikłą reprezentacją szlachty. Nie przeszkodziło to biskupowi w odprawieniu nabożeństwa i odśpiewaniu Te Deum ${ }^{30} .22$ czerwca wydał obiad na cześć rosyjskich dowódców ${ }^{31} .25$ czerwca przy wtórze kościelnych hymnów i pod przewodnictwem Józefa Kazimierza ogłoszono Akt Konfederacji Generalnej Litewskiej; odbyły się bale, a Kossakowski wznosił toasty za zdrowie imperatorowej rosyjskiej Katarzyny ${ }^{32}$. Jego zadaniem stało się ugruntowanie władzy konfederackiej na Litwie ${ }^{33}$.

\footnotetext{
22 D. Rolnik, O postawach szlachty..., dz. cyt., s. 83.

23 Tamże, s. 87.

24 Tamże, s. 89.

25 Zob. A. Wolański, Wojna..., dz. cyt., s. 184.

26 Tamże, s. 19.

27 D. Rolnik, 0 postawach szlachty..., dz. cyt., s. 87.

28 W. Smoleński, Konfederacja ..., dz. cyt., s. 108.

29 Tamże, s. 111.

30 A. Wolański, Wojna..., dz. cyt., s. 182-183.

31 Tamże, s. 184.

32 W. Smoleński, Konfederacja ..., dz. cyt., s. 113.

33 Tamże, s. 118-119.
} 
Bracia liczyli, że na czele konfederacji na Litwie stanie Szczęsny Potocki i zostawi im wolną rękę ${ }^{34}$. Ostatecznie wybrano starego Aleksandra Sapiehę 35 , który był figurantem. Rozpoczął się okres grabieży, której Kossakowscy dokonywali aż do początków kolejnego roku ${ }^{36}$. W dobie trudnych relacji pomiędzy konfederacjami Józef Kazimierz stał się ważną postacią. Próbował publicznie bronić swojego postępowania ${ }^{37}$. W pierwszej połowie sierpnia zarówno król jak i Kreczetnikow chcieli, aby pojechał do Warszawy i był przeciwwagą poczynań Szczęsnego Potockiego wobec monarchy38. Nie widząc w tym interesu, Kossakowski odmówił. Poważną rolę odegrał za to w trakcie połączenia konfederacji w Brześciu, gdzie przewodniczył nabożeństwom ${ }^{39}$. Wraz z bratem brał udział w destrukcji nowego ustroju, a obaj skorzystali np. na zwiększeniu roli hetmanów ${ }^{40}$.

Głosy sprzeciwu formułowane przeciwko działaniom konfederackim $^{41}$ spotkały się z repliką. Uwagi nad pismem pod tytułem Uniwersał do narodu pod dniem (...), dawniej przypisywane raczej Józefowi Nepomucenowi Kossakowskiemu, prawdopodobnie wyszły spod pióra Józefa Kazimierza ${ }^{42}$, który skupiał się na personalnym atakowaniu twórców konstytucji i wychwalaniu „wielkiej Katarzyny”. Pisał o reformatorach, że „(...) świętych zażywają wyrazów dla zamydlenia oczu ludzi poczciwych, ludzi w dobrej wierze ojczyznę swoją kochających, żeby wydarłszy im majątki, wydarli im jeszcze i życie (...)"43. Dodawał

34 W. Smoleński, Konfederacja ..., dz. cyt., s. 263-264.

35 Tamże, s. 265.

36 D. Rolnik, O postawach szlachty..., dz. cyt., s. 82.

$37 \mathrm{~W}$ tym celu opublikował dwie broszury. Zob. J. K. Kossakowski, Spowiedź polityczna, albo wyznanie polityczne przekonania, Grodno 1792; Tenże, Pamiętnik, albo zbiór krótki obchodzq̨cych szczególniej naród polski wiadomości dla oświecenia i pokazania prawdy stanu rzeczy polskich, b.m.w., 1792. Zob. też: M. Rutkowska, Józef Korwin Kossakowski [w:] T. Kostkiewiczowa (red.), Pisarze Polskiego Oświecenia, Warszawa 1994 , s. 373.

38 W. Smoleński, Konfederacja ..., dz. cyt., s. 256-257.

39 Tamże, s. 304.

40 Tamże, s. 295.

41 M. Rutkowska, Józef Korwin Kossakowski.., s. 372.

42 Tamże.

43 J. K. Kossakowski, Uwagi nad pismem ..., dz. cyt., k 1. 
Kamil Michaluk - Upadek u szczytu kariery...

frazesy o odebraniu im prawa głosu na sejmikach i zmuszeniu do płacenia na wojsko ${ }^{44}$; wyliczał: Ignacego i Stanisława Kostkę Potockich, Adama Czartoryskiego i Hugona Kołłątaja. Zarzucał im dobranie sobie „fircyków bez żadnej eksperiencji (...) żeby ci hersztowie rabowali skarb, roztrwonili go na metresy, na ekwipaże, na zbytki i mieli zaraz w pogotowiu wojsko, które by ich broniło (...)"45. Podsumowaniem słów przeciwko „machiawelskim układom” były fragmenty dotyczące „najcnotliwszej monarchini”: ,jeżeli Imperatorowa JM mogła dać większy dowód cnoty i dobroci serca swojego, jak wyrywając nas z paszczęki tych zajadłych kanibalów"46.

Mniej istotne, że to postępowanie rodziny Kossakowskich było obliczone na odebranie majątku innym. Józef Kazimierz i jego kompani zostali wyzwani do literackiego i polemicznego pojedynku ${ }^{47}$ przez Juliana Ursyna Niemcewicza, który w październiku 1792 r. wydał Fragment Biblie targowickiej. Księgi Szczęsnowe ${ }^{48}$. Sporo miejsca poświęcił Józefowi Kazimierzowi, którego wywodził od Sieciecha, Chmielnickiego, Radziejowskiego i innych zdrajców ${ }^{49}$. Ostatni rozdział opowiadał o tym, jak Szczęsnemu Potockiemu objawił się w krzewie gorejącym Bóg-Kossakowski i wskazał, co ma czynićs0:

I rzekł Kossakowski: zostawiam ci zupełnie Koronę, ty mi rządy Litwy zostawisz (...) rozerwałem już wszystkie związki, które Koronę z Litwą łączyć mogły (...) zostają mi jeszcze cztery ważne zamysły: wynieść ród mój i obdarzyć go pierwszymi urzędami (...). Być prezesem nie edukacji, ale dóbr edukacyjnych w Litwie (...). Wydrzeć administrację ekonomii królewskich (...), przenieść do siebie (...) opiekę majątku radziwiłłowskiego (...). Z tymi sposobami któż mi zaprzeczy, że nie będę panem całej Litwy (...)? $?^{51}$

44 Tamże, k 1.

45 Tamże, k 2.

46 Tamże, k 3.

47 Więcej o oświeceniowych polemikach: A. Kwiatkowska, Piórowe wojny. Polemiki literackie polskiego Oświecenia, Poznań 2001.

48 J. U. Niemcewicz, Fragment Biblie Targowickiej...., dz. cyt.,

49 Tamże, s. 10.

50 Tamże, s. 13.

51 Tamże, s. 15-16. 
Józef Kazimierz odpowiedział w Kontynuacji Fragmentu Biblie targowickiej. Zachował stylistykę, całkowicie zmieniając wydźwięk utworu i odwracając akcenty. Bronił polskiego Mojżesza, który wybawić miał naród od „plag egipskich” przyniesionych przez Sejm Wielki ${ }^{52}$. Zwraca uwagę fakt, że Józef Kazimierz nie pozwalał sobie wówczas na atakowanie króla. Być może zdawał sobie sprawę, że jakaś forma współpracy z monarchą może być jeszcze przydatna jego rodzinie.

W okresie pomiędzy jesienią 1792 i wiosną roku następnego postępowała dekonstrukcja porządku wprowadzonego przez Sejm Czteroletni. Szymon Kossakowski w lipcu 1793 roku ogłosił się w miejsce Michała K. Ogińskiego hetmanem wielkim litewskim ${ }^{53}$, a Józef Kazimierz został 3 kwietnia 1793 roku zarządcą dóbr biskupa krakowskiego ${ }^{54}$. Biskup miał duży udział w wydzieleniu Komisji Skarbowej dla Litwy i wprowadzeniu wyższego kursu rubla srebrnego na terytoriach litewskich ${ }^{55} .27$ kwietnia 1793 roku doszło do likwidacji Komisji Edukacji Narodowej i powstania dwóch odrębnych ciał ${ }^{56}$. Kossakowski, jako przewodniczący w Wielkim Księstwie Litewskim, zwolnił swojego brata Antoniego z długu wobec Komisji (50 tys. zł), zaś sam sobie przyznał 160 tys. zł wynagrodzenia ${ }^{57}$. W styczniu 1793 roku wyswatał swojego bratanka z córką Szczęsnego Potockiego58. Ważnym momentem, które także zadecydowało o dalszych losach biskupa, był moment zagarnięcia Wielkopolski przez Prusy. ${ }^{59}$ Szymon Kossakowski, mający pod sobą znaczną ilość wojska, groził nawet atakiem na

52 M. Rutkowska, Józef Korwin Kossakowski..., dz. cyt., s. 374-375.

53 Buchholtz à Frédéric Guillaume II, Grodno, 27 I 1793 [w:] Targowica i sejm grodzieński..., dz. cyt., s. 89.

${ }^{54}$ Zob. L. Żytkowicz, Ferdynand Kontrym [w:] PSB, t. XIII, s. 607-608.

55 M. Rutkowska, Józef Korwin Kossakowski..., dz. cyt., s. 374- 375.

56 Zob. J. Lewicki, Komisja Edukacji Narodowej w świetle ustawodawstwa szkolnego. Szkic historyczny, Warszawa 1923, s. 10, 12.

57 M. Rutkowska, Józef Korwin Kossakowski..., dz. cyt., s. 374-375.

58 Tamże, s. 374.

${ }^{59}$ Zob. W. A. Serczyk, Katarzyna II, Wrocław 2004, s. 294. 
Kamil Michaluk - Upadek u szczytu kariery...

Wielkopolskę ${ }^{60} .23$ stycznia 1793 roku kraj opuścili Szczęsny Potocki i Seweryn Rzewuski61. Wydawało się, że znaczenie Kossakowskich wzrośnie. Wystąpiły jednak komplikacje. Największą z nich była misja Jakoba Sieversa, który zastąpił Jakowa Bułhakowa jako posła nadzwyczajnego i ministra pełnomocnego Katarzyny II w Polsce ${ }^{62}$. Pogardzał on Kossakowskimi, czemu dał wyraz w swoich pamiętnikach. Zależało mu na unormowaniu życia w kadłubowym państwie tak, by mógł przeprowadzić sejmową ratyfikację rozbioru ${ }^{63}$. Grabieże biskupa, hetmana i ich ziomków spowalniały pacyfikację.

„Przeprowadzenie rozbioru” wymagało zapoznania się z lokalną polityką, z tego powodu działania Sieversa miały charakter rozpoznawczy ${ }^{64}$. Musiał wysondować zgodę kręgów kościelnych na wykonanie poleceń płynących z dworu Katarzyny II. Na początku marca upewnił się co do tego, że nie napotka protestów ze strony nuncjusza papieskiego Marii Saluzzo, który pisał do kanclerza koronnego Jacka Małachowskiego:

Ojciec Święty, zezwalając na przeniesienie święta św. Stanisława czynił to w zaufaniu, że odmiana ta raczej przydać mogła świetności nabożeństwa (...) lecz wyrażana w tejże nocie chęć narodu skonfederowanego w Targowicy, dawszy poznać Ojcu Św., iż przeniesienie takowe nie mogłoby tylko przeciwny oczekiwaniom jego sprawić skutek, Ojciec Św. bez trudności zezwolił, ażeby rzeczone święto jak dotąd obchodzone było (... ${ }^{65}$.

Biskupi wierni konfederacji także nie próżnowali. Wsławił się zwłaszcza Ignacy Jakub Massalski, który w liście pasterskim zachęcał „(...) aby we wszystkich kościołach (...) śpiewano suplikację, dodając

60 Pewnych cennych informacji faktograficznych dostarcza wiekowa praca D. Iłowajskiego. Zob. D. Iłowajski, Sejm grodzieński roku 1793. Ostatni sejm Rzeczypospolitej Polskiej, Poznań 1872, s. 33.

${ }^{61}$ M. Rutkowska, Józef Korwin Kossakowski..., dz. cyt., s. 374.

62 Tamże, s. 27-28.

${ }^{63}$ B. Grochulska, P. Ugniewski, Wstęp [w:] J. J. Sievers, Jak doprowadziłem do drugiego rozbioru..., dz. cyt., s. 11.

64 D. Iłowajski, Sejm grodzieński..., dz. cyt., s. 27.

${ }^{65}$ Nota nuncjusza papieskiego Marii Saluzzo do kanclerza wielkiego Jacka Małachowskiego, Warszawa, 7 III 1793 [w:] 0. Beiendorf (oprac.), Papiestwo wobec sprawy polskiej w latach 1772-1864. Wybór źródet, Wrocław 1960, s. 59. 
na końcu: «abyś Skonfederowanym Stanom i ich marszałkom Twej pomocy i rady dodawać raczył, prosimy Cię Panie»"66. Nadchodzący sejm w Grodnie był przedostatnim już akordem w karierze Józefa Kazimierza. Kossakowscy nie wpisywali się w plany Sieversa, który pragnął uspokojenia kraju i ratyfikacji traktatów. Interweniowali w Petersburgu, pragnąc wykorzystać niechęć Markowa czy Zubowa wobec posła ${ }^{67}$. Kurlandczyk wygrał i w razie potrzeby był gotów „poświęcić Kossakowskich”. ${ }^{68}$ Jego „Pamiętniki”69 przybliżają działania Józefa Kazimierza w tym okresie: „(...) Na ich czele stoi biskup Kossakowski. Jest on wierny, lecz obawia się równie o dobro Kościoła świętego, jak i starostwa (...)”70. W innym miejscu czytamy, że „(...) Biskup w ogólności uchodził za najnikczemniejszego człowieka na Litwie, jeżeli go w tym hetman nie wyprzedzał"71. Sievers zamierzał ukrócić ich nadużycia, tym samym wystawiał ich wierność wobec Katarzyny II na próbę ${ }^{72}$.

Politykę Kossakowskich cechowały umiarkowanie wrogie zachowania wobec monarchy i niechęć do Prus. Ludwig Buchholtz w swoich relacjach jeśli już pisał o Kossakowskim , to raczej jako o prusofobie i małostkowym polityku ${ }^{73}$. Stosunek biskupa do Stanisława Augusta lapidarnie ujął Sievers, pisząc: „(...) jestem bowiem przekonany, że jedynym ich systemem jest we wszystkim stawiać opór królowi i upokarzać go, jak znowu system całej familii królewskiej jest Kossakowskich poniżać" 74 .

${ }^{66}$ List pasterski biskupa wileńskiego Ignacego Jakuba Massalskiego do duchowieństwa i wiernych, Grodno, 12 III 1793 [w:] Papiestwo wobec sprawy polskiej... , dz. cyt., s. 318.

67 B. Grochulska, P. Ugniewski, Wstęp..., dz. cyt., s. 10.

68 J. J. Sievers, Jak doprowadziłem do drugiego rozbioru..., dz. cyt., s. 101.

${ }^{69} \mathrm{~W}$ gruncie rzeczy jest to nie pamiętnik, ale kompilacja jego korespondencji po części przepisanej, po części streszczonej przez Karla Ludwiga Bluma. Por. K. L. Blum, Drugi rozbiór Polski z pamiętników Sieversa, Poznań 1865.

70 J. J. Sievers, Jak doprowadziłem do drugiego rozbioru..., dz. cyt., s. 61.

71 Tamże, s. 106.

72 Tamże, s. 77.

73 Buchholtz à Frédéric Guillaume II, Grodno, 29 VI 1793 [w:] H. Kocój (oprac.), Targowica i sejm grodzieński 1793 w relacjach posła pruskiego Buchholtza, Kraków 2004, s. 130-131.

${ }^{74}$ J. J. Sievers, Jak doprowadziłem do drugiego rozbioru..., dz. cyt., s. 144. 
Kamil Michaluk - Upadek u szczytu kariery...

Sievers i jego stronnicy chcieli przeforsować plany rozbiorowe drogą przekupstwa. Kossakowski, jak twierdził Antoni Trębicki ${ }^{75}$, wziął na siebie całą Litwę. Sievers przechwalał się, że „cała Litwa kosztuje może 200 dukatów na posła"76. Józef Kazimierz spośród wszystkich zainteresowanych pobrał od posła najwięcej, bo 4 tysiące dukatów ${ }^{77}$. Ostatecznie stawiło się zaledwie czterech senatorów ${ }^{78}$. Później frekwencja polepszyła się, jednak widoczne było, że deputaci niechętnie widzieli swoją obecność na sejmie zatwierdzającym rozbiór. Sievers parł do rozwiązania konfederacji targowickiej, co miało odebrać Kossakowskim prawo do sądownictwa wyjątkowego ${ }^{79}$. Stało się to faktem 15 września, a sejm unieważnił niektóre z „sancitów"80.

Biskup był wśród członków delegacji zapraszającej Sieversa do Grodna ${ }^{81}$; stwierdził, że przyjaźń z Rosją jest podstawą bytu dla kraju ${ }^{82}$. Należało „(..) poddać się najjaśniejszej imperatorowej jmci pod warunkami zapewniającymi nam religię panującą, prawa, swobody i wolności nasze aniżeli na rozbiór kraju zezwalać"83. 12 lipca król wyznaczył 31 członków deputacji do rozmów z Sieversem ${ }^{84}$. Rozegrały się dramatyczne boje o poszerzenie uprawnień deputacji, próba dyktatu i groźby ze strony posła rosyjskiego ${ }^{85}$. Król preferował praktykę odraczania sesji, w czym pomagał mu Kossakowski86. Jak napisał Antoni Trębicki: „(...) spadać poczynała zasłona (...) osoby roztropniejsze zawsze widziały w Kossakowskich ludzi złych i przewrotnych, którzy na to tylko się maskowali w sejmie, iżby ująć rozjątrzone

\footnotetext{
${ }^{75}$ A. Trębicki, Opisanie sejmu..., dz. cyt., s. 49.

76 J. J. Sievers, Jak doprowadziłem do drugiego rozbioru..., dz. cyt., s. 97.

77 Tamże.

${ }^{78}$ A. Trębicki, Opisanie sejmu..., dz. cyt., s. 61.

79 J. J. Sievers, Jak doprowadziłem do drugiego rozbioru..., dz. cyt., s. 118.

80 Zob. Ł. Kądziela, Między zdradq a służbq Rzeczypospolitej. Fryderyk Moszyński w latach 1792-1793, Warszawa 1993, s. 204-216.

81 J. J. Sievers, Jak doprowadziłem do drugiego rozbioru..., dz. cyt., s. 75.

${ }^{82}$ A. Trębicki, Opisanie sejmu..., dz. cyt., s. 76.

83 Tamże, s. 102.

84 J. J. Sievers, Jak doprowadziłem do drugiego rozbioru ..., dz. cyt., s. 119.

85 M. K. Ogiński, Pamiętniki..., s. 192- 193. Zob. też: R. H. Lord, Drugi rozbiór Polski, Warszawa 1984, s. 262-271.

${ }^{86}$ A. Trębicki, Opisanie sejmu..., dz. cyt., s. 105- 106.
} 
przeciwko swym nieprawościom obywatelskie serca"87. W kolejnych zdaniach dodawał, że nie byli oni wierni nawet wobec Sieversa.

Delegacja przeszła po interwencji zwolenników Józefa Kazimierza, którą ten próbował maskować kolejnym przemówieniem ${ }^{88}$. Uchwały zostały podyktowane przez Sieversa; Kossakowski dopomógł w ich przeprowadzeniu, a król nazwał go „cnotliwym prałatem”89. Liczba wrogów rosła; cieszył fakt, że zakończenie sejmu zbiegło się z dymisją Sieversa ${ }^{90}$. Jego następca, Josip Igelström, miał doprowadzić państewko do upadku; przywrócono prawa targowickie, w czym udział miał Józef Kazimierz ${ }^{91}$. Dbając o rodzinne finanse, stał się bliskim współpracownikiem carskiego generała, co nie uszło uwadze opinii publicznej i nieprzychylnych ludzi pióra92.

Obecność patriotów z Tadeuszem Kościuszką w Dreźnie, radykalizacja w stolicy i pogłoski o planowanym powstaniu nie dawały biskupowi spokojnie spać. Miał skłonność do depresyjnych stanów już w wcześniej, co wiemy z jego wspomnień i relacji postronnych. Często towarzyszyło mu poczucie schyłkowości, osamotnienia, zdania tylko na własną rodzinę, co skutkowało zachowaniem kogoś, kto nie ma już nic do stracenia. Biskup świetnie wpisywał się w styl polityki uprawiany przez Josipa Igelströma ${ }^{93}$. Sievers raportował następcy, że nie bez powodu nie zdecydował się na umieszczenie Józefa Kazimierza w Radzie Nieustającej, ponieważ pragnął zachowania spokoju ${ }^{94}$. Kossakowskich oskarżał o to, że sejm trwał dłużej i kosztował więcej, niż powinien ${ }^{95}$. Jego nazwisko pojawiało się $\mathrm{w}$ relacjach Jana Jakuba Patza, przedstawiciela Saksonii w Warszawie. Jak pisał 12 lutego 1794

87 Tamże.

88 Tamże, s. 117.

89 Tamże, s. 179.

90 M. K. Ogiński, Pamiętniki..., dz. cyt., s. 240- 241.

91 M. Rutkowska, Józef Korwin Kossakowski..., dz. cyt., s. 375.

92 Tamże.

93 Więcej o zasadniczych punktach tej polityki może powiedzieć instrukcja Katarzyny II przeznaczona dla generała. Zob. J. Sievers, Jak doprowadziłem do drugiego rozbioru..., dz. cyt., s. 191-192.

94 Tamże, s. 187.

95 Tamże, s. 190. 
Kamil Michaluk - Upadek u szczytu kariery...

roku: „Do Warszawy przybył biskup inflancki Kossakowski. Trudno jest przewidzieć do czego zostanie wykorzystana jego osoba i jaką odegra rolę"96. Później dodawał, że „wydaje się odgrywać teraz jedną z głównych ról na tutejszej scenie. Uczestniczy we wszystkich konferencjach, jakie odbywają się u barona Igelströma"97. Nerwowa sytuacja w stolicy była podsycana przez spiski, które stale tropiono ${ }^{98}$. Igelström, strasząc widmem „paryskich scen”, podjął decyzję o redukcji polskiej armii ${ }^{99}$. Zdawano sobie sprawę, że grozi to wybuchem rebelii, jednak zrazu rosyjski poseł tylko wsłuchiwał się w „głosy stolicy". Oczy otworzyła mu dopiero awantura wywołana przez Antoniego Madalińskiego i jego brygadę, co $\mathrm{w}$ rezultacie przyspieszyło decyzję drezdeńskiej emigracji o powstaniu ${ }^{100}$. Pomyłką było ogołocenie stolicy z oddziałów, które wymaszerowały w kierunku Małopolski101.

Wrażenie w Warszawie po bitwie racławickiej (2 kwietnia 1794 r.) było na tyle silne, że dostrzegano odradzanie się „klubów i zgromadzeń"102. Inny błąd carskiego przedstawiciela trafnie zdiagnozował A. Trębicki, gdy pisał:

„Igelström (...) całą swą ufność w przebiegłym i niedocieczonym generale Cichockim ${ }^{103}$, dowódcy artylerii i komendancie garnizonu polskiego w stolicy, położył. Umiał ten oficer tak daleko omamić i Ożarowskiego, i Kossakowskich, i generalicję moskiewską względem arsenału i wielkości regimentów warszawskich, że mu niemal zupełnie władzę nad nimi powierzono (...)”104.

Okoliczność ta okazała się zgubna 17 kwietnia, kiedy gen. Cichocki miał udział w zdobyciu arsenału, uzbrajaniu ludności i dowodzeniu walczącymi ${ }^{105}$. Wybór dnia na wybuch insurekcji nie był przypadko-

\footnotetext{
96 J. J. Patz, Z okien saskiej ambasady..., dz. cyt., s. 26.

97 Tamże.

98 M. K. Ogiński, Pamiętniki ..., dz. cyt., s. 249-250.

99 Tamże, s. 253.

100 Tamże, s. 254; J. J. Pistor, Pamiętniki o rewolucji polskiej ..., dz. cyt., s. 29, 31.

101 Tamże, s. 19.

102 Tamże, s. 30.

103 Zob. R. Morcinek, Jan August Cichocki [w:] PSB, t. IV, s. 20-21.

104 A. Trębicki, Opisanie sejmu..., dz. cyt., s. 233.

105 B. Szyndler, Powstanie kościuszkowskie 1794, Warszawa 1994, s. 33, 44.
} 
wy. Jan Kiliński twierdził, że dostał od Augustyna Karskiego, sekretarza rosyjskiej ambasady106, kopię listu, w którym Kossakowski doradzał Igelströmowi perfidny sposób rozbrojenia warszawskich arsenałów i ludności, do czego użyć miano wojska. Doradzał, by oddziały pod wodzą Piotra Ożarowskiego asystowały w trakcie nabożeństw wielkosobotnich. Biskup diecezjalny zarządzić miał msze rezurekcyjne we wszystkich świątyniach o godzinie dwudziestej, aby wojsko rosyjskie otoczyło i rozbroiło cywili i wojskowych: „(...) a gdyby tego nie chcieli uczynić, to każ ich kartaczami wysiec (...)"107. Trudno było o bardziej jaskrawy dowód zdrady.

O świcie 19 kwietnia 1794 r. „znienawidzony od tłumu” Kossakowski mógł przeczuwać tragedię; pozostał w mieszkaniu na warszawskim Lesznie. Paląc osobiste papiery i rękopisy własnych dzieł literackich $^{108}$, liczył na jakąś formę pacyfikacji siłami rosyjskimi109. 0 czwartej rano zapukali do jego drzwi insurgenci ${ }^{110}$. Zastali go śpiącego; kiedy $\mathrm{w}$ toku rozmowy wydało się, że ma być odstawiony do prochowni, próbował wykręcić się od aresztowania. Okoliczności aresztowania opisał Jan Kiliński: „(...) pyta się czy asystencja dla niego będzie. Dają mu odpowiedź, że asystencję (...) mieć będzie, jako to: on pierwszy, drugi hetman Ożarowski, trzeci Zabiełło, czwarty Ankwicz, co biskupa prowadzić będą, to tych bardzo wielu". Zapewnienia, że pośle kanonika, a sam potrzebuje lekarza, wywołały wściekłość powstańców, którzy go „(...) zaprowadzili do prochowni, ale tak mocno był zapaskudzony, że patrzeć na koszulę i gatki nie było można"111. Załamanego Kossakowskiego ${ }^{112}$ nie podtrzymał na duchu Ożarowski:

106 J. Kiliński, Pamiętniki..., dz. cyt., s. 51.

107 Tamże, s. 49.

108 M. Rutkowska, Józef Korwin Kossakowski.., dz. cyt., s. 375.

109 Tamże, s. 376.

110 J. Kiliński, Pamiętniki ..., s. 90.

111 Tamże, s. 91.

112 Tamże, s.. 95- 96. 
„Przynajmniej mnie będzie miał kto błogosławić, ale któż, jeżeli nie na szubienicę (...). Pójdźmyż (...) tam jak najprędzej stanąć"113.

Po uformowaniu Rady Zastępczej Tymczasowej ${ }^{114}$ ustanowiono Sąd Kryminalny i deputację, mającą zbadać dokumenty przechwycone przy zatrzymanych; zakazano im wszelkiej komunikacji115. 22 kwietnia zajęto się administracją majątku J. K. Kossakowskiego'116. Niedługo potem dotarła do niego wstrząsająca wiadomość: „hetman Kossakowski, który kazał strzelać ze swego domu do pospólstwa, został uwięziony. Po krótkim procesie kryminalnym(...) został powieszony w godzinach popołudniowych 25 b.m. pod ratuszem miejskim"117. Przyspieszyło to kolejne egzekucje ${ }^{118}$, a dzielna postawa brata ${ }^{119}$ nie była chyba pocieszeniem. 5 maja aresztowano Ignacego Massalskiego, Wojciecha Skarszewskiego i Fryderyka Józefa Moszyńskiego ${ }^{120}$. Posłano do nuncjusza z prośbą o „zdjęcie z Kossakowskiego święceń”. Wawrzyniec Litta odpowiedział dyplomatycznie:

Panowie (...), tylko jeden Ojciec Święty ma moc z biskupa zdejmować sakry (...). Ale skoro się okazuje to, że on zbrodnię w swojej ojczyźnie popełnił, a więc przez to wszystkie sacra zmazał. Więc kiedy go sąd winnym kary śmierci znajduje, a zatem nie stracą oni jako biskupa, ale tylko łotra, który się dopuścił występku złego ${ }^{121}$.

Nuncjusz posłał kanonika, który symbolicznie „zdjął święcenia”'122. Więźniów oddano pod Sąd Kryminalny pod presją ludu123. Groziło powtórzenie rozruchów z dnia 8 maja. Linia obrony duchownego była dość naiwna. Stwierdził, że:

113 Tamże, s. 91 Alternatywna informacja o zatrzymaniu: J. J. Patz, Z okien saskiej ambasady..., dz. cyt., s. 62.

${ }^{114}$ Akty Powstania Kościuszki..., cz. I, Kraków 1918, s. 7.

115 Tamże, s. 17, 20, 22.

116 Tamże, s.. 26.

117 J. J. Patz, Z okien saskiej ambasady..., dz. cyt., s. 77.

118 Tamże, s. 79.

${ }^{119}$ A. Śliwiński, Powstanie kościuszkowskie, Warszawa 1917, s. 114-115.

120 Akty Powstania..., dz. cyt., s. 79.

121 J. Kiliński, Pamiętniki..., dz. cyt., s. 115.

122 M. Rutkowska podaje, że był to bp Cinna Antonin Malinowski. M. Rutkowska, Józef Korwin Kossakowski..., dz. cyt., s. 376.

${ }^{123}$ Akty Powstania ..., dz. cyt., s. 126-130. 
Oto ja byłem niechętnym ku Polsce, że mi nie dano biskupstwa krakowskiego, które na mnie przypadało. (...) zostałem wzgardzony od tutejszego pospólstwa, a potrzeba wiedzieć sądowi, żem ja jest nietutejszy, a osoba każdego biskupa jest ona święta i nietykalna. Sąd, jeżeli ma coś do niego, to powinien na ukaranie odesłać do monarchini, do Petersburga ${ }^{124}$.

Ostatnie słowa zdawały się raczej pogrążyły Kossakowskiego, podobnie jak przyznanie się do autorstwa pacyfikacji. Po krótkim procesie, podobnie jak P. Ożarowski, J. Ankwicz i J. Zabiełło, został skazany na śmierć, samemu podpisując dekret. Szubienica przeznaczona dla biskupa ustawiona została na Krakowskim Przedmieściu, przed kościołem Bernardynów125. Jak relacjonował Kiliński:

(...) Kossakowski miał śmierć najokropniejszą, a to z tej przyczyny, że wychodząc z ratusza, zaraz mu pokazano już wiszącego hetmana Ożarowskiego, marszałka litewskiego Zabiełłę, marszałka koronnego Ankwicza, a nawet pytano go o to, czyli on ich poznaje. A obywatele, skoro go tylko przed ratuszem ujrzeli, tak wielki krzyk i szczęk bronią zrobili, że on prawie na wpół umarłym został 126 .

Pamiętnikarz przytoczył jeszcze opowieść o tym, jak to Kossakowski, ponieważ chciał przyjąć komunię, został wpuszczony do kościoła Bernardynów - tam zaś miał czekać na niego ratunek i schronienie ${ }^{127}$. Samemu sobie przypisywał udaremnienie ostatniej szansy ratunku, na jaką mógł liczyć biskup ${ }^{128}$. Ostatnim chwilom Józefa Kazimierza Kossakowskiego towarzyszył gniew tłumu:

A przy tym był niezmierny krzyk od ludu wydany, a do tego jeszcze jednemu broń wtenczas wystrzeliła. Kossakowski rozumiał, że to do niego strzelać będą, i tak się bardzo zaląkł, że go prawie już nieżywego powieszono, bo gdy mu [mistrz] stryczek na szyję założył i opuścił go, tak Kossakowski ani się nie ruszył, ani zipnął, ale jak snop słomy wisiał. Ale też tak mocno był zapasku-

\footnotetext{
124 J. Kiliński, Pamiętniki..., dz. cyt., s. 116.

125 M. Rutkowska, Józef Korwin Kossakowski..., dz. cyt., s. 376.

126 J. Kiliński, Pamiętniki..., dz. cyt., s. 117.

127 Tamże, s. 116- 17.

128 Tamże.
} 
Kamil Michaluk - Upadek u szczytu kariery...

dzony od kobiet, że aż strach na niego patrzeć było. Tak to Kossakowski biskup życie swe skończył (....”"129.

Ciało biskupa ekshumowano dopiero w grudniu 1794 roku i pochowano w rodzinnym Janowie, który w 1797 roku wykupił Szczęsny Potocki i po latach ofiarował stryjecznemu wnukowi biskupa, Stanisławowi Kossakowskiemu ${ }^{130}$.

Tragiczny finał kariery Józefa Kazimierza Kossakowskiego poniekąd przesłonił ją samą. Znamy go bardziej z Wieszania Jarosława Marka Rymkiewicza i inspirujących je grafik Jana Piotra Norblina, niż poważnych prac historycznych. Filolog stwierdził przy tym, że:

Biskup nie był może wielkim pisarzem, ale jeśli chodzi o poziom intelektualny, to niewątpliwie stał najwyżej spośród wszystkich powieszonych w roku 1794 , więc szkoda, że nie poznamy tych poematów, które spalił, może trochę pochopnie ${ }^{131}$.

Niewątpliwie charakteryzował się bystrym intelektem, wykraczającym poza horyzonty ludzi takich, jak Piotr Ożarowski czy Józef Ankwicz.

Przykład Kossakowskiego pokazuje, że chęć łatwego przyporządkowania danej postaci sprzyja nadinterpretacjom. Był zdrajcą w równym stopniu, jak przez pisarstwo i system wartości był oświeconym sarmatą. Dodać należy, że warunki, w których żył, sprzyjały wypaczeniom i sprawiały, że w polityce wygrywał silniejszy, obdarzony silniejszą protekcją. Biskup był postacią, która nie pozwalała, by rządził jej życiem przypadek. Charakter i ambicja cechowały jego podejście do życia i w jakimś sensie przywiodły do popełnionych przestępstw. Prace dotyczące Kossakowskiego mogą wnieść nieco do rodzimej humanistyki w kontekście oceny postaw przeciwnych dziełu reform osób, które uważa się za zdrajców. Poznanie ich motywacji i życiowych priorytetów wiele tłumaczy. Podobny charakter miały w przeszłości ustalenia autorstwa Łukasza Kądzieli dotyczące Fryderyka Moszyń-

\footnotetext{
129 Tamże, s. 118.

130 M. Rutkowska, Józef Korwin Kossakowski..., dz. cyt., s. 376.

131 J. M. Rymkiewicz, Wieszanie, Warszawa 2007, s. 100.
} 
skiego. Obaj oni wymykali się standardowym ocenom, łączyli w swojej karierze działalność postępową, reformatorską i zdradę polityczną. Kossakowski zaś był przykładem jednostki, która musiała szukać trwałej protekcji, a okazją do zrobienia prawdziwej kariery stał się dla niego występek. Takich karier można wyróżnić u schyłku I Rzeczypospolitej więcej.

\section{Bibliografia:}

\section{Źródła:}

Akty Powstania Kościuszki, oprac. Sz. Askenazy, W. Dzwonkowski, t. I, Protokoły i dzienniki Rady Zastępczej Tymczasowej i Rady Najwyższej Narodowej, cz. I, Wyd. Akad. Umiejętności, Kraków 1918.

Karpiński, Franciszek, Pamiętniki, Wyd. W. Stefański, Poznań 1884.

Kiliński J., Pamiętniki, oprac. S. Herbst, Warszawa 1958.

Kitowicz J., Pamiętniki, czyli Historia polska, oprac. P. Matuszewska, Warszawa 1971.

Kopeć J., Dziennik (...) brygadiera wojsk polskich, Warszawa 1975.

Kossakowski J. K., Pamiętnik, albo zbiór krótki obchodzących szczególniej naród polski wiadomości dla oświecenia i pokazania prawdy stanu rzeczy polskich, b. m., 1792.

Kossakowski J. K., Spowiedź polityczna, albo wyznanie polityczne przekonania, Grodno 1792.

Kossakowski J. K., Uwagi nad pismem pt. Uniwersał do narodu pod dniem 29 maja 1792, b. m., 1792.

Luchesini G., Listy do Fryderyka Wilhelma II. Obraz sejmu wielkiego w raportach pruskiego dyplomaty, oprac. H. Kocój, Warszawa 1988.

Niemcewicz J. U, Fragment Biblie Targowickiej. Księgi Szczęsnowe, Frankfurt 1793.

Ogiński M. K., Pamiętniki Michała Ogińskiego o Polsce i Polakach, t. 1, Wyd. J. Żupański, Poznań 1870.

Papiestwo wobec sprawy polskiej w latach 1772-1864. Wybór źródeł, oprac. 0. Bejendorf, Wrocław 1960. 
Kamil Michaluk - Upadek u szczytu kariery...

Patz J. J., Z okien saskiej ambasady. Warszawa 1784 roku $w$ świetle relacji dyplomatycznych przedstawiciela Saksonii w Polsce, Wyd. Z. Libiszowska, H. Kocój, Warszawa 1969.

Pistor J. J., Pamiętniki o rewolucji polskiej roku 1794, oprac. B. Cholewiński, Warszawa 1906.

Sievers J. J., Jak doprowadziłem do drugiego rozbioru Polski, Wyd. Interim, Warszawa 1992.

Targowica i sejm grodzieński 1793 w relacjach posła pruskiego Buchholtza, oprac. H. Kocój, Kraków 2004.

Trębicki A., Opisanie sejmu 1793 r. O rewolucji 1794 r., Wyd. J. Kowecki, Warszawa 1962.

\section{Opracowania:}

Blum K. L., Drugi rozbiór Polski z pamiętników Sieversa, Wyd. J. Żupański, Poznań 1865.

Butterwick R., Polska rewolucja a Kościół Katolicki 1788-1792, Wyd. Arcana, Kraków 2012.

Butterwick R., Bishop Józef Kazimierz Kossakowski at the Four Years' Diet, [w:] R. Šmigelskytė-Stukienè (red.), Lietuvos Didžiosios Kunigaikštystès istorijos kraštovaizdis. Moksliniu straipsniu rinkinys Skiriama profesorès Jūratès Kiaupienés 65-mečiui, Vilnius 2012, s. 389- 412.

Derdej P., Zieleńce- Mir- Dubienka, Wyd. Bellona, Warszawa 2008.

Grochulska B., Ugniewski P., Wstęp, [w:] J. J. Sievers, Jak doprowadziłem do drugiego rozbioru Polski, Wyd. Interim, Warszawa 1992.

Grześkowiak-Krwawicz A., Zdrada trzeciego maja? Malkontenci wobec ustawy Rzq̨dowej [w:] A. Grześkowiak-Krwawicz (red.), Bo insza rzecz jest zdradzić, insza dać się złudzić. Problem zdrady w Polsce przełomu XVIII i XIX w., Wyd. IBL PAN, Warszawa 2005, s. 69-89.

Iłowajski D., Sejm grodzieński roku 1793. Ostatni sejm Rzeczypospolitej Polskiej, Wyd. J. Żupański, Poznań 1872.

Kądziela Ł., Między zdradq a służbq Rzeczypospolitej. Fryderyk Moszyński w latach 1792-1793, Wyd. Volumen, Warszawa 1993.

Kwiatkowska A., Piórowe wojny. Polemiki literackie polskiego Oświecenia, Wyd. Sorus, Poznań 2001.

Kwiatkowska- Jeznach E., Sejmiki lutowe 1792 r. w relacjach „Gazety Narodowej i Obcej” $i$ „Gazety Warszawskiej”, „Acta Universitatis Lodziensis”. Folia Historica 92, 2014, s. 49-63. 
Lewicki J., Komisja Edukacji Narodowej w świetle ustawodawstwa szkolnego.

Szkic historyczny, Wyd. Księgarnia Polska, Warszawa 1923.

Lord R., Drugi rozbiór Polski, Wyd. Pax, Warszawa 1984

Łojek J., Dzieje zdrajcy. Szczęsny Potocki, Wyd. Alfa, Warszawa 1995.

Morcinek R., Jan August Cichocki, [w:] „Polski Słownik Bibliograficzny” 1938, t. IV, s. 20-21.

Nowak J., Satyra polityczna Sejmu Czteroletniego, Wyd. Kasa Mianowskiego, Kraków 1933.

Rolnik D., O postawach szlachty litewskiej wobec konfederacji targowickiej w 1792 roku, „Wschodni Rocznik Humanistyczny” 2004, Nr 1.

Rolnik D., Portret szlachty czasów stanisławowskich epoki kryzysu, odrodzenia i upadku Rzeczypospolitej w pamiętnikach polskich, Wyd. UŚ, Katowice 2009.

Rutkowska M., Józef Korwin Kossakowski, [w:] T. Kostkiewiczowa (red.), Pisarze Polskiego Oświecenia, Wyd. PWN, Warszawa 1994, s. 356-386.

Reychman J., Historia Turcji, Wyd. Ossolineum, Wrocław 1973

Rymkiewicz J. M., Wieszanie, Wyd. Sic!, Warszawa 2007.

Serczyk W. A., Katarzyna II, Wyd. Ossolineum, Wrocław 2004.

Smoleński W., Konfederacja targowicka, Kraków 1903.

Smoleński W., Ostatni rok Sejmu Wielkiego, Wyd. Gebethner i Wolff, Kraków 1897.

Szczygielski W., Referendum trzeciomajowe. Sejmiki lutowe 1792, Wyd. UŁ. Łódź 1994.

Szyndler B., Powstanie kościuszkowskie 1794, Wyd. Ancher, Warszawa 1994.

Śliwiński A., Powstanie kościuszkowskie, Wyd. M. Arct, Warszawa 1917.

Wolański A., Wojna polsko-rosyjska 1792 r. Kampania litewska, Wyd. K. Rzepecki, t. II, Poznań 1924.

Zielińska Z., Aleksander Michał Sapieha, [w] „Polski Słownik Bibliograficzny” 1994, t. XXXV, s. 565-569.

Zielińska Z., Jan Suchorzewski, [w:] „Polski Słownik Bibliograficzny” 20072008, t. XLV, s. 315-324.

Żytkowicz L., Ferdynand Kontrym, [w:] „Polski Słownik Bibliograficzny” 1967-1968, t. XIII, s. 607-608. 